CDI

26,4

562

Received 29 November 2018 Revised 23 April 2019 Accepted 6 August 2019

\section{Shocks and entrepreneurship: a study of career shocks among newly graduated entrepreneurs}

\author{
Sophie Rummel, Jos Akkermans, Rowena Blokker and \\ Marco Van Gelderen \\ Department of Management and Organization, School of Business and Economics, \\ Vrije Universiteit Amsterdam, Amsterdam, The Netherlands
}

\begin{abstract}
Purpose - The purpose of this paper is to explore the career shocks that young, newly graduated entrepreneurs experience in the process of starting a business.

Design/methodology/approach - The study adopted a qualitative approach, drawing upon 25 semistructured interviews with entrepreneurs who recently graduated from university (up to the age of 30) in different European countries.

Findings - The analysis identifies several career shocks that can confront entrepreneurs before and after starting a business and reveals how these shocks influence graduates' decisions to become and continue to be an entrepreneur.

Research limitations/implications - The study sheds light on the diverse nature of career shocks and the importance of integrating agency concepts and environmental influences in career research. It identifies important factors relevant for school-to-work transition research and complements work in entrepreneurship research on necessity and opportunity entrepreneurship, push and pull motives, and entrepreneurial intentions.

Practical implications - Organizations can use the findings to attract and retain young entrepreneurial employees, while higher education organizations can use the findings to better prepare students for a successful transition into entrepreneurship, whether in the corporate or independent form.

Originality/value - The paper integrates the concept of career shocks with literature on entrepreneurship and offers a categorization of career shocks in the pathway to entrepreneurship.
\end{abstract}

Keywords Entrepreneurship, Career decisions, Career shocks, School-to-work transition, Youth entrepreneurship

Paper type Research paper

There was this one moment where I was at home, and I had an Airbnb guest over. He was an experienced entrepreneur from the States. And he told me to start - like right now. (Respondent 4)

The Respondent described an unexpected influential meeting with a guest which led to selfreflection and subsequently led him to start his own business. The above quote shows the influence of the unexpected event of receiving advice from an experienced foreign entrepreneur on this individual's career. Studying the role of such external events on an individual's career decision making and development has begun to gain momentum in scholarly literature. Indeed, contemporary career research has predominantly focused on individual agency aspects of careers, thereby putting less emphasis on the influence of external events (Akkermans et al., 2018). However, such unpredictable and unplanned events happen to most people, and they can have a strong influence on their careers (Hirschi, 2010).

(C) Sophie Rummel, Jos Akkermans, Rowena Blokker and Marco Van Gelderen. Published by Emerald Publishing Limited. This article is published under the Creative Commons Attribution (CC BY 4.0) licence. Anyone may reproduce, distribute, translate and create derivative works of this article (for both commercial \& non-commercial purposes), subject to full attribution to the original publication and authors. The full terms of this licence may be seen at http://creativecommons.org/licences/by/4.0/ legalcode.
Career Development International Vol. 26 No. 4,2021 pp. 562-581

Emerald Publishing Limited $1362-0436$

DOI 10.1108/CDI-11-2018-0296 
Therefore, there is a need to further understand the phenomenon of career shocks and their impact on careers (Akkermans et al., 2018; Seibert et al., 2013).

Career shocks can be defined as "disruptive and extraordinary events that are, at least to some degree, caused by factors outside the focal individual's control and that trigger a deliberate thought process concerning one's career" (Akkermans et al., 2018, p. 4) and, thus, can make career opportunities salient (Seibert et al., 2013; Slay et al., 2006). Career shocks can be a positive or negative experience and can have an impact on peoples' careers in terms of, for example, decisions, development and success. Importantly, a career shock triggers a deliberate thought process regarding career options - it does not necessarily need to lead to a career change and can even result in an individual becoming more resolved to follow their current career path. Thus, a career shock is an intrapsychic response to an external event. By focusing on these career shocks, the first contribution of this study is that it heeds calls for a stronger integration of contextual factors in career research to study agentic and non-agentic factors in career development in concert (e.g. Akkermans and Kubasch, 2017; Inkson et al., 2012; Mayrhofer et al., 2007).

We also respond to calls for more research on the occurrence and impact of career shocks among particular groups (Akkermans et al., 2018; Seibert et al., 2013). In this study, we are specifically interested in the role of career shocks among young entrepreneurs who recently obtained a university degree, and we investigate the kinds of career shocks that these newly graduated entrepreneurs have experienced as well as the impact of these shocks on their careers. In contemporary career theories such as the protean career (Hall, 2004) and the boundaryless career (Arthur et al., 2005), career options such as entrepreneurship have increasingly become a viable vocational choice in today's labor market. This makes it important to study entrepreneurship from a career perspective (Burton et al., 2016; Van Gelderen et al., 2008). Furthermore, the literature on the school-to-work transition primarily focuses on the transition from education to employment in organizations, whereas transitions into business ownership are, for the most part, excluded from research designs (cf. $\mathrm{Ng}$ and Feldman, 2007). It is likely that young people generally experience shocks during the school-towork transition (Akkermans et al., 2015). However, the transition into entrepreneurship is different from the transition into an organizational position, as the transition into entrepreneurship can be characterized as having less predefined pathways for career development (Nabi and Holden, 2008; Nabi et al., 2010). This potentially makes newly graduated entrepreneurs more prone to the occurrence of career shocks. Thus, the second contribution of this study is to extend the school-to-work transition literature, as these "non-typical" types of transitions appear to become more prevalent in contemporary labor markets and are currently understudied in school-to-work transition research (cf. Kalleberg and Marsden, 2015; Ng and Feldman, 2007).

The third contribution of this study is to connect the notion of career shocks to concepts in the entrepreneurship literature. The role of external events as a trigger of entrepreneurship has been explicitly acknowledged in such notions as necessity and opportunity entrepreneurship (Bosma and Harding, 2006), and push and pull entrepreneurship (Amit and Muller, 1995). However, the two distinctions are critiqued (Dawson and Henley, 2012; Nabi et al., 2015) because entrepreneurship literature uses push/pull and necessity/ opportunity as static and binary constructs. Studies typically assign entrepreneurs to one or the other category, and then study relations of being in one such category with other variables. In contrast, career shocks are ongoing, and can belong to multiple categories (e.g. the same individual can experience both push and pull shocks). Thus, the career shocks concept can help to complement these static dichotomies. Moreover, work on career shocks complements other concepts of entrepreneurial career decision making such as entrepreneurial intent (Krueger et al., 2000). In intention models such as the Theory of 
CDI

26,4

564

Planned Behavior, intentions are formed based on beliefs regarding desirability, feasibility and norms. Career shocks explain when and how these beliefs change.

In sum, this qualitative empirical study investigates the role of career shocks among newly graduated entrepreneurs who obtained a university degree. It examines the concept of career shocks by uncovering the various types of career shocks graduates experience during the transition from university to entrepreneurship.

\section{Theory}

Career shocks

Career shocks have been conceptualized as external career events that are, at least in part, unexpected and outside of the individual's control. Furthermore, such career shocks lead to a deliberate thinking process that may (or may not) lead to a subsequent career change (Akkermans et al., 2018). To illustrate, losing one's job after unexpectedly being laid off would be considered a career shock, whereas losing one's job willingly after resigning would not. In terms of the potential impact of a career shock, while some people might deliberately decide to continue on the same career path and aim to find employment in a similar position, others might decide to change their path (e.g. Baruch et al., 2016). For example, moving into entrepreneurship. In sum, career shocks constitute an event that leads to a deliberate thinking process that can subsequently lead to an individual taking action. The subjective experience of a career shock needs to be separated from the possible outcome of a career shock such as a career change (Akkermans et al., 2018).

Next to the defining attributes of being unexpected and outside of someone's control, prior research has also emphasized that career shocks can have a positive (e.g. a promotion) or negative (e.g. losing a mentor) valence (e.g. Holtom et al., 2005), and that this can have a differential impact on someone's career. For example, individuals who experienced a positive shock showed increased intentions to apply for graduate education, whereas those experiencing a negative shock were more likely to actually apply (Seibert et al., 2013). Furthermore, Lee and Mitchell (1994) investigated career shocks as a factor for voluntary turnover and noted that shocks can occur in different domains: personal and job-related (or: professional). According to Lee and Mitchell (1994), shocks such as marriage, pregnancy or an inheritance can be considered personal shocks, whereas unexpected job offers or promotions can be considered professional shocks.

Research on career shocks and their impacts on careers is sparse. However, because career shocks can lead to career changes via a deliberate thinking process, they represent a key driver of transitions, career decisions and career development (Akkermans et al., 2018; Bright et al., 2005; Slay et al., 2006). The few studies that have been done in this area showed, for instance, that unplanned events had an influence on school-to-work transitions and perceived transition success (Hirschi, 2010), and that career shocks affect young employees' decision to pursue graduate education (Seibert et al., 2013). Furthermore, several studies examined the role of career shocks in employees' decision to quit (e.g. Morrell et al., 2004). Similarly, to the valence of the shock itself, the impact on an individual's career caused by career shocks can be positive or negative (Seibert et al., 2013). A shock with a positive valence is likely to have a positive impact on someone's career, whereas negative shocks are events that will likely have a negative impact (Akkermans et al., 2018). This is illustrated by a recent study showing that positive career shocks strengthen young employees' efforts to attain career success and build their employability, whereas negative career shocks undermine this process (Blokker et al., 2019). However, some studies found counter-intuitive relationships, in which negative career shocks can have a positive outcome (e.g. Baruch and Lavi-Steiner, 2015). An example of this could be someone finding their calling as an entrepreneur after being unexpectedly laid off in a corporate organization. Furthermore, as the perception and deliberate thinking process of 
career shocks are subjective, individuals can differ in their reaction toward them (Burton et al., 2010) and the perceived outcome may change over time (Chen, 2005).

Careers are less linear than they may have been in decades past (Arthur et al., 2005; Hall, 2004), and it is important to outline how career shocks differ from regular, normal events affecting the progress of an individual's career. In this study's definition, career shocks are external unexpected events that cause a significant deliberate thinking process concerning one's career (Akkermans et al., 2018). Not all career transitions are necessarily preceded by a career shock, in the sense of a precipitating event that causes a deliberate thinking process about career options. An individual may switch employers, a position within the organization, or even become an entrepreneur without any career shock being involved. However, given changing global and economic realities, the occurrence of career shocks may be increasingly frequent, particularly when it concerns entrepreneurial careers. Thus, career shocks are becoming a more prominent part of careers, making the study of career shocks more urgent and relevant than ever.

\section{Entrepreneurship and career shocks}

Even though entrepreneurship research has been conducted since the 1960s, a large variety of definitions of entrepreneurship continue to exist (Bruyat and Julien, 2001; Nabi et al., 2006). Entrepreneurship has been conceptualized narrowly in terms of starting a business, and more broadly referring to entrepreneurial traits, skills and attitudes such as risk-taking (Nabi and Holden, 2008; Van Gelderen et al., 2008). This study adopts the narrow definition because the research focuses on the career shocks that graduates experience in the process of starting a business and how they influence careers, rather than the traits, skills or attitudes that influenced their entrepreneurial decisions. This study characterizes newly graduated entrepreneurs as individuals who started a business during or shortly after obtaining a university degree. Although everyone can encounter career shocks (Chen, 2005), the school-to-work transition is an especially likely career phase in which to experience career shocks as it is often a phase of many challenges and changes (Akkermans et al., 2015). This might be even more applicable to newly graduated entrepreneurs as they do not have the support of the corporate environment and often lack human, social and financial capital (Hulsink and Koek, 2014). Nevertheless, the specific transition into entrepreneurship and the underlying mechanisms are not sufficiently studied in the school-to-work transition literature (e.g. Ng and Feldman, 2007).

The entrepreneurship literature captures the external events and circumstances influencing entrepreneurial career choice in terms of necessity (vs opportunity) and push (vs pull) entrepreneurship. Necessity entrepreneurs are those who "are pushed into entrepreneurship because all other options for work are either absent or unsatisfactory" (Bosma and Harding, 2006, p. 15). Conversely, opportunity entrepreneurs voluntarily opt for entrepreneurship in pursuit of benefits such as higher income and independence. Similarly, push factors comprise impulses such as redundancy, a lack of alternative career options and dissatisfaction with the current job, whereas pull factors are influences that attract people into business ownership, such as independence, increased earnings and the perception of a market opportunity (Amit and Muller, 1995; Kautonen and Palmroos, 2010).

The career shock construct represents an opportunity for the conceptual development of entrepreneurship literature because the distinctions mentioned above are critiqued on various grounds. First, the distinctions are commonly used in a binary and static manner. Individuals are classified as either necessity (push) or opportunity (pull) entrepreneurs, and once assigned to one such category, they are kept in this category. For example, the Global Entrepreneurship Monitor - which covers 54 economies and 68 percent of the world population - uses survey items to classify respondents as being either necessity or opportunity entrepreneurs, and reports that 74 percent of entrepreneurs around the world have started businesses in pursuit

\section{A study of career shocks}


CDI 26,4

of an opportunity rather than out of necessity (GEM, 2018). In contrast to this static distribution, career shocks are ongoing events, and the construct of career shocks does not singularly focus on the decision to become an entrepreneur. Entrepreneurs can experience shocks before, during and following the process of starting a business. This contrasts with the static classifications of necessity/opportunity and push/pull. Related to this is the fact that individuals can experience both positive and negative career shocks (e.g. Seibert et al., 2013; Blokker et al.,2019). This contrasts with the common practice of classifying entrepreneurs to a single binary category, even though research finds that push and pull factors operate concurrently (Nabi et al., 2015).

Second, unlike the shock construct, which is grounded in actual events, the necessity (push) and opportunity (pull) distinctions rest on superordinate classifications and are therefore ambiguous. For example, individuals are considered to be pulled toward entrepreneurship if they are triggered by factors such as income and independence, but the same factors can just as well be considered push or necessity factors if the current work situation is deficient in these regards. Similarly, one can be concurrently pushed by current financial distress and pulled by the perception of a lucrative market opportunity (Dawson and Henley, 2012). In contrast, a career shock is a construct grounded in actual events, rather than being a superordinate classification. As such, research on career shocks does not assume that a particular event will reside in a particular superordinate category, but rather asks the respondent because the same event can trigger quite different deliberate thought processes. To illustrate, starting a venture out of a situation of unemployment is typically classified as "push" or "necessity" without inquiring into the specifics of the context. However, the individual involved could have voluntarily and volitionally quit their job to start a new venture. Career shocks can trigger both necessity (push) and opportunity (pull), and as such, the construct shows the significance of external events regardless of the type of entrepreneurship. Although a distinction such as necessity/opportunity could also be used in a dynamic and non-binary manner, this is not done, to our knowledge, as it is used to classify individuals into a type of entrepreneurship.

It is important to point out that whereas the necessity/opportunity and push/pull categories can be applied to every case, not everyone becomes an entrepreneur because of a precipitating event causing a deliberate thinking process (Lerner et al., 2018). For example, someone who grew up in a family business and joins the leadership team may not do so because of a career shock. Another person may have felt an affinity to entrepreneurship for as long as he or she can remember. A third person may join a group of friends in starting a new venture, without giving career considerations much thought.

Beyond push/pull and necessity/opportunity, the career shock construct can be integrated with the intention models commonly used in studies of entrepreneurial career choice (Krueger et al., 2000). Career shocks provide one explanation for why intentions and their antecedents change (cf. Nabi et al., 2010). For example, in the Theory of Planned Behavior, intentions are predicted from the proximal factors attitude (desirability), perceived behavioral control (feasibility) and social norms. Measurement is based on the assessment of beliefs relevant to these three components. Career shocks provide one explanation for why these beliefs change, as the events and subsequent reflection involved in a shock may result in changed beliefs (or the weight attached to these beliefs) about the three components.

The study of career shocks brings us back to the lineage of studies that originates with Shapero and Sokol's (1982) model of the entrepreneurial event. According to Shapero (1984), the company formation process begins with a trigger leading someone to change their life path. Like the career shock literature, Shapero and Sokol (1982) discern not only negative triggers, such as war, migration, losing a job; but also, positive pulls such as an investment offer or support from a spouse. The empirical research regarding these triggers into entrepreneurship is somewhat limited. One exception is the work of Voutsina et al. (2014), who investigated shocks as a drastic event that lead an employee to the decision to quit their job 
and start a business. They found several work and home-related shocks with external and internal sources that triggered employees to start a business. We aim to fill this gap in the literature by studying the career shocks of newly graduated entrepreneurs.

\section{Method}

Research design

This study utilized a qualitative research method to inductively gain insight into the types of career shocks that newly graduated entrepreneurs encountered, and how they impacted their careers. To enhance the understanding of the personal experiences of graduates experiencing career shocks, semi-structured interviews were conducted. For the purpose of having a representative sample and following studies from entrepreneurship research (McLarty, 2005; Nabi et al., 2009, 2010) and school-to-work transition research (Brzinsky-Fay, 2007), a timeframe of a maximum five years after graduating from university was used when selecting respondents. As the data were collected during Spring 2018, the study included participants who graduated between 2013 and 2018.

\section{Sample and sampling frame}

Purposive sampling was adopted to identify potential interviewees. An entrepreneur was defined narrowly as a recently graduated individual who started a business. Participants who did a part-time master's or worked next to the start-up were included as they considered themselves entrepreneurs and were active in the business. Business creation may have already started during the respondents' studies.

The interviewee selection process started with a call on LinkedIn and Facebook with a description of the target group. Furthermore, universities offering entrepreneurship specialization programs were contacted. Additionally, potential respondents were contacted directly via LinkedIn based on the visible information available on their profiles. In the second stage, the snowball technique was adopted to gain further access to possible participants (Browne, 2005). In total, 27 semi-structured interviews with entrepreneurs were conducted. However, two interviews were excluded from the analyses as one participant started the business before being part of a study program and the other did not attend higher education.

The final sample consisted of 25 newly graduated entrepreneurs with an age range of between 22 and 30 years of age. To ensure anonymity, the participants were labeled with a capitalized $\mathrm{R}$ and their number (R1, R2, etc.). We aimed to optimize heterogeneity in interviewees' study background and businesses to obtain variation in terms of career shocks and their impact on individuals' careers. Most businesses were founded in the Netherlands $(n=16)$. Other countries were Germany $(n=5)$, Austria $(n=2)$ and the UK $(n=2)$. The sample was predominantly male $(n=19)$, which is representative of the situation for Europe as fewer women found their own company (Kollmann et al., 2016). Most respondents founded their company shortly after or in the same year as their graduation. Some founded their company while they were still studying. The earliest founding of a business by a respondent was in 2013. The newest founding of a business by a respondent in the sample was in 2018. Table I provides an overview of the respondents' characteristics.

The semi-structured interviews lasted between 30 and $90 \mathrm{~min}$. The time difference primarily arose in the introductory part of the interview, when we asked about the respondent's current venture. Most interviews lasted around $1 \mathrm{~h}$, and there was no difference in the quality of the interviews. The interviews were conducted in person or via Skype in English and were recorded and transcribed. Based on the conceptualization of Akkermans et al. (2018), participants were asked to recount positive, negative, unexpected and extraordinary events that triggered them to think about their career deliberately. For each shock, participants were asked about the potential impact on their career. 
CDI
26,4

568

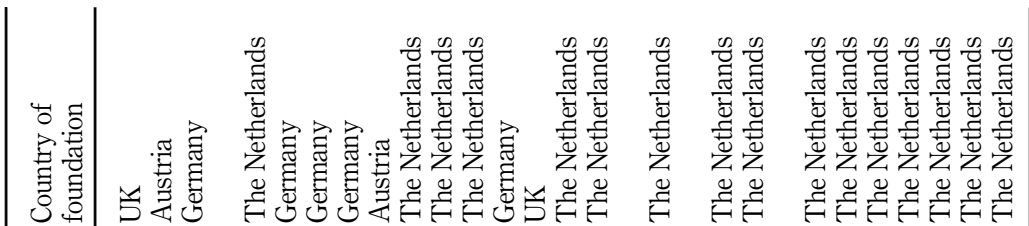

$\underline{568+.}$

Table I.

Sample characteristics

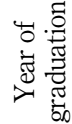

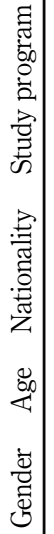

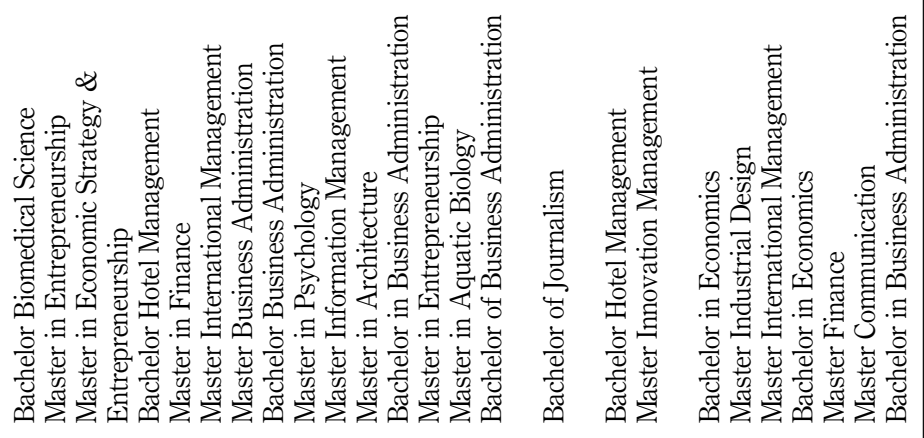

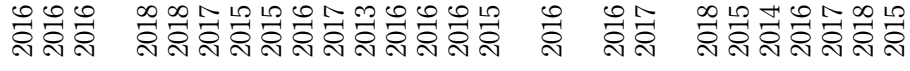

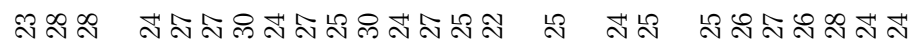

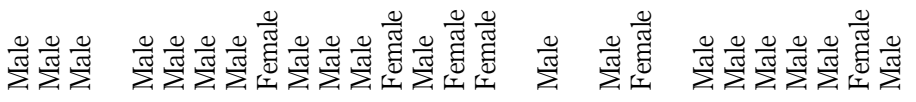

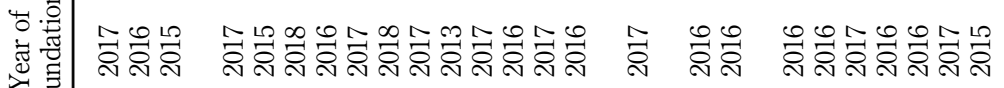

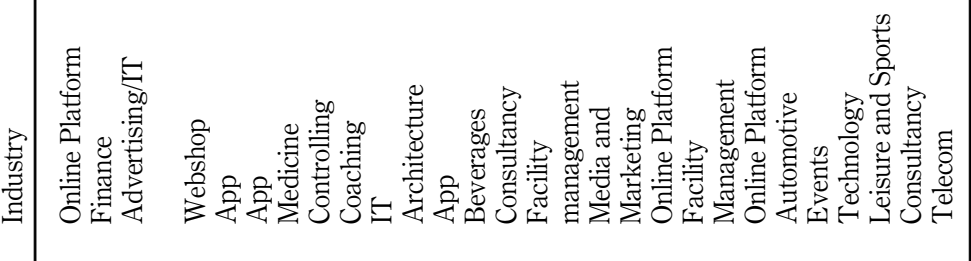
宊 
Data analysis

The data analysis used the Gioia method, which separates the coding process into three steps: first-order concepts, second-order themes and aggregated dimensions (Gioia et al., 2012). Based on the research question and interview protocol, the analysis followed the initial distinction between positive and negative career shocks. During the data analysis, it became apparent that the respondents experienced different career shocks before vs after starting up the business. The coding process was then performed for each group of career shocks separately based on their valence (positive/negative) and their temporal differentiation (before/after starting a business). The computer software MAXQDA supported the data analysis.

As a first step, statements referring to significant moments and their impacts were grouped with the use of open coding and in vivo coding (Locke, 2001). By using constant comparison (Corbin and Strauss, 1990, p. 9) statements were added, codes adjusted and categories changed. During the process, the researchers stayed as close as possible to the collected data (Locke, 2001). After coding the transcripts, relationships and patterns between the first-order categories were examined (Gioia et al., 2012). Based on similarities and differences, second-order themes were formed by going back and forth between the categories and consulting the literature (Gioia et al., 2012). From the second-order themes, the aggregated dimensions emerged as a third step. The coding process was performed separately, meaning coding was done, respectively, for positive/negative career shocks and before/after starting a business, and then similarly for the impacts of shocks on their careers. Afterwards, we examined the interplay between shocks and impacts by going back to the transcripts, exploring how the career shocks that we found in the data might relate to certain impacts. The connections between career shocks and career impacts are presented with arrows in Figures 1 and 2.

\section{Findings}

Our findings showed clear patterns of a temporal distinction of career shocks. Some shocks happened before or in the very early beginning of the starting up process, whereas others occurred after the business was founded. Based on the aggregated dimensions we found, this section presents the positive career shocks before starting a business and their impact,
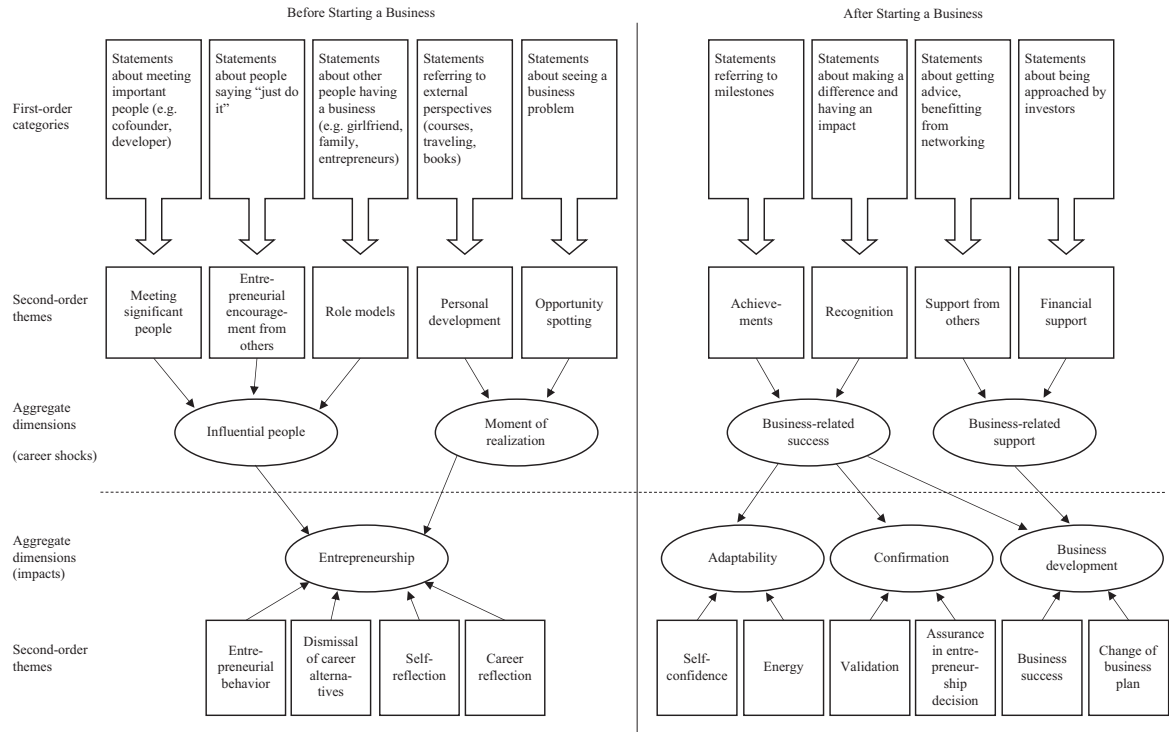

A study of career shocks 
CDI

26,4

570

Figure 2.

Negative career shocks before and after

starting a business and their impacts
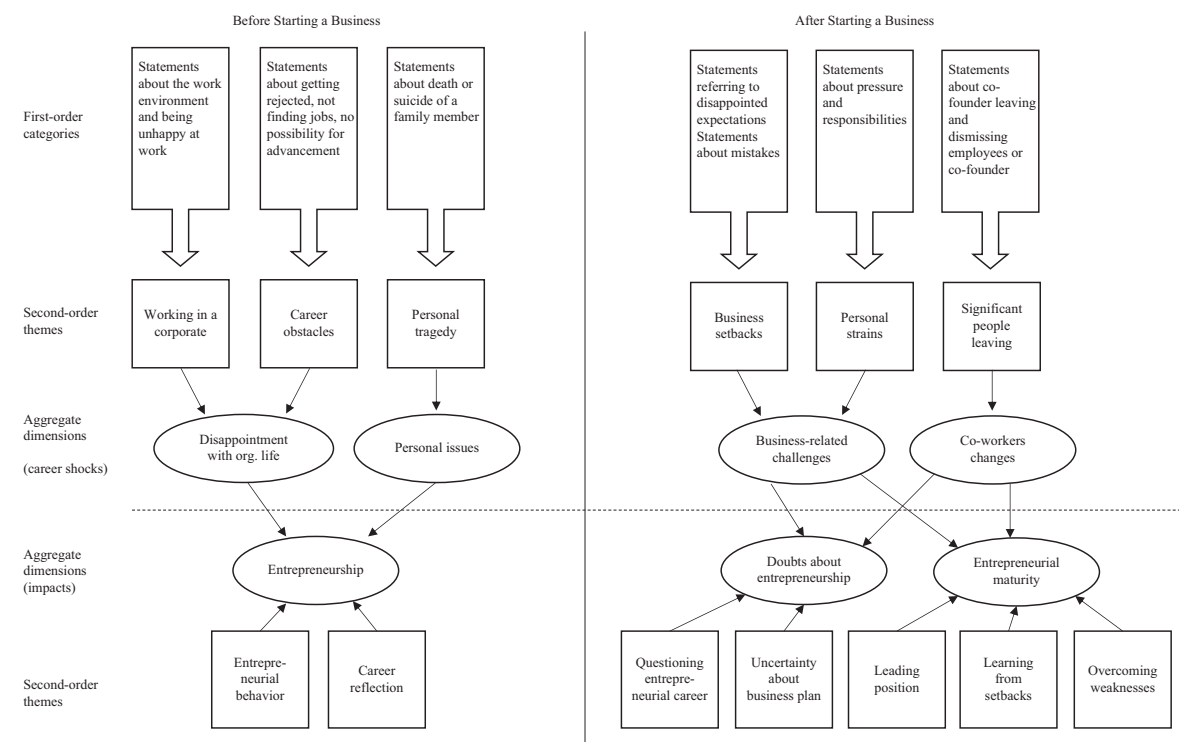

followed by positive career shocks after the founding of the business and their impact (see Figure 1). The same structure is then used to present the negative shocks before starting a business and after the founding of the business (see Figure 2).

\section{Positive career shocks before starting a business}

The positive career shocks before the founding of the business can be classified as personal shocks involving encounters with influential people, and moments of realization.

Influential people. During the analysis, it became apparent that other people play an important role for newly graduated entrepreneurs. Meeting significant people, getting entrepreneurial encouragement and having a role model were brought forward as positive personal shocks. Several respondents referred to unexpected meetings with significant people, such as being introduced to a future co-founder (R1) or meeting people who strongly influenced the business development (R6, R11). Other influential people were role models who generated entrepreneurial awareness. For example, seeing one's girlfriend in the process of founding a business (R8). Finally, entrepreneurial encouragement from other people was mentioned in this category. Respondents described friends, family members or teachers as factors that pulled them into entrepreneurship:

I had no idea what entrepreneurship was before that one friend said, "Well go and do what you are talking about". (R19)

Moments of realization. Another type of a positive shock that occurred before starting a business was unexpected insights, for example from traveling, reading an inspiring book and participating in a lecture or course. All these activities gave the respondents a different perspective and made them realize things about certain aspects of their lives. For example, Respondent 9 described a book which helped him to become conscious about his trouble with working in a corporate environment and provided him with a solution to find a new purpose. Another prominent theme, opportunity spotting, relates to moments of realization regarding the business. Respondents talked about unexpected situations in which they recognized that 
there was a problem. For instance, Respondent 14 spoke about a sudden confrontational moment during a university course in Singapore about the plastic problem in the sea:

That was really a moment like wow [we] really need to do something about this now. (R14)

Or Respondent 8 who said:

When I had realized that the market leader in the pharmaceutical industry thought it was cheaper to develop their own solution than buying one which is already on the market, that hit me. (R8)

Impact of positive career shocks before starting a business

Positive career shocks before starting a business influenced some of the respondents' careers as they led them toward entrepreneurship.

Entrepreneurship. Ultimately, the positive shocks of influential people and moments of realization can act as a trigger toward entrepreneurship by evoking entrepreneurial behavior, by influencing the dismissal of career alternatives, and by causing career and self-reflection. Entrepreneurial behavior refers to starting up a business as well as looking for opportunities. As an illustration, one respondent narrated how an Airbnb guest, an experienced entrepreneur, encouraged him to start up their business:

This was actually the same night where I created the logo of the company and the first website of the company. [...] Because directly one day afterward was when I then went together with him [co-founder] and started [it] all off. (R4)

For another respondent (R17), the shock of getting encouragement for his idea from a teacher caused him to start his business earlier than he planned. Furthermore, Respondent 3 described the impact of a university course as a moment of realization that entrepreneurship has always been part of his life and states:

But the course basically showed me that I should try to force to get this opportunity. (R3)

Another theme was the dismissal of career alternatives. Respondents reported that they never looked for a regular job (R10) or rejected job offers (R12):

This was during my masters and you know then I would say: okay I really want to try this, and I won't look for a job afterwards. But I will really do this. (R6)

Positive shocks of realizations triggered entrepreneurship by causing respondents to reflect on themselves and their careers. Respondents described how shocks lead them to rethink what is important in their lives and referred to experiencing different career concepts and evaluating career paths. Another respondent described how a course influenced him:

[I gained] clarity for my wish to become an entrepreneur and I understood much better why I wanted to be an entrepreneur. (R3)

\section{Positive career shocks after starting a business}

Whereas positive career shocks before starting a business were predominantly personal, the positive shocks experienced after the business were founded featured mostly businessrelated success and support, which can be classified as professional shocks.

Business-related success. Within the dimension of business-related success, achievement describes any significant moment in which the newly graduated entrepreneur achieved a major success in the context of the business. Several respondents mentioned moments in which activities or results happened for the first time such as their first pitch, signing the first client or their first time seeing the product:

For the first time after all the theory to have like a real looking thing even though when I look at it now the design was horrible. (R12)

A study of
career shocks 
CDI 26,4

One respondent recounted unexpectedly getting their first big assignment (R24). Others described winning awards or competitions with their business (R1, 14, 17).

Also related to business success is recognition, for example being invited for drinks by a famous football coach (R21) or the realization that the company was becoming successful (R22). Although also related to the business, those shocks present accomplishments more on a personal level as the Respondent gained a sense of making progress or doing something meaningful. Respondent 5 discussed the following moment:

I realized that the product [and] what we do or the things we do [. . . is on [the] one hand useful and also can create jobs. (R5)

Business-related support. Support from significant others was important after the founding of the business. This represents moments in which newly graduated entrepreneurs got unexpected advice from more experienced entrepreneurs in situations where they did not directly anticipate getting any guidance, and which led them to think about and evaluate their current business strategy. Therefore, the shocks can be classified as professional shocks as the advice that the respondents mentioned focused on the business. Next, financial support is a major theme that appeared throughout the interviews. Significant moments originated from receiving financial advice and finding or being approached by an investor. For example, Respondent 17 illustrates a significant moment:

[. . . ] when serious investors came to us, and they were CEOs of pretty big companies, so [they] were really wealthy persons. (R17)

\section{Impacts of positive career shocks after starting a business}

After starting the business, positive career shocks influenced newly graduated entrepreneurs on a personal and professional level as they influenced the business's development, the adaptability of the graduate and lead to the confirmation of their career path in entrepreneurship.

Business development. An impact of positive shocks after the founding of the business was the businesses development. Respondents described how the career shocks of businessrelated success and support influenced their business. For example, statements referred to business success as a "stepping stone" (R15) for the business and to changes in the business plan and how the business is run. To further illustrate this, Respondent 1 talked about how an award changed "the direction in which we are taking the company." Several statements also related to the product or the service the entrepreneur offered being used by customers:

And that sort of went out of [our] hands in that sense. We didn't expect that it would be so big and that we would get invited by all those Dutch television programs. (R20)

Adaptability. Next to the impact that they had on the business, career shocks related to business success also influenced the newly graduated entrepreneurs personally. Respondents described an increase in self-confidence and energy that helped them to continue with the process, to further improve and deal with challenging situations. One respondent described how winning an award gave him confidence in the business (R1), whereas Respondent 12 stated that after seeing the finished product for the first time she gained a "confidence boost." Business success generated an "extra drive" (R17) and "lots of energy" (R21) for the respondents.

Confirmation. Another impact of positive shocks was that entrepreneurs felt externally validated in their career path as an entrepreneur as they received recognition for their business and felt that their work was worthwhile. As a result of business success, newly graduated entrepreneurs also gained the feeling of increased capability when they achieved something:

So, I think it [getting the first big assignment] was a bit of an endorsement of the things and the way we are doing it. (R24) 
Additionally, the positive shocks also contributed to the feeling of assurance in the decision to become an entrepreneur:

[Signing our first client] definitely gave me validation that I am on the right track. (R14)

The above-listed impacts illustrate the point that career shocks lead to deliberate thinking and reflection, but not necessarily to a change in career. For some respondents, career shocks led to a consolidation of their decision to be a business owner. For others, the career shocks led to the decision to scale up the business.

\section{Negative career shocks before starting a business}

Newly graduated entrepreneurs also experienced negative career shocks before and after starting their business. Negative career shocks before starting the business were connected to disappointment with organizational life and personal issues.

Disappointment with organizational life. One important type of negative shock related to disappointing experiences in an organization. The majority of respondents expressed negative experiences during internships or first working experiences that led them to evaluate their current situation. Common patterns were dissatisfaction with characteristics of working in a corporate company, such as high levels of hierarchy, not enough independence, or the general work environment:

I [...] knew also from my internship in the industry in the 6th or 7th semester that corporate life would definitely set the boundaries for me too high and I wouldn't feel happy in a corporation. (R7)

Another respondent described being unhappy with the development of the company:

That it just was all about the money now not for a good purpose. (R9)

Other career shocks are related to organizational career obstacles. Career obstacles can be rejections for a position or not finding employment in a certain area of interest. One respondent recalled how she could not advance further in an organization.

Well, they straight out said "you are not at senior level yet. Come back in 8 years." That was a huge

"okay your career ends here now". (R14)

Personal issues. The newly graduated entrepreneurs experienced personal tragedies such as suicide or death within the family. Although these shocks were not close to starting up a business, these significant moments influenced the respondents strongly:

My mom passed away when I was 11. [. . . I I think that is one of the most important things which contributed to the way I am now. (R25)

\section{Impact of negative career shocks before starting a business}

Negative careers shocks often had the impact of pushing young people into entrepreneurship, rather than the predominantly pulling effect of the positive shocks before starting a business.

Entrepreneurship. Negative career shocks can be determinants for graduates to go into entrepreneurship. Negative shocks before starting the business such as being disappointed with an organizational career were especially influential as they evoke entrepreneurial behavior. The impact did not have to accrue directly, but graduates may have first reflected on their career or taken the first steps in the direction of entrepreneurship. Career reflections were related to respondents' experiences in an organization as well as to personal issues:

I just hit a wall, and that made me realize that there was no way for me that I could go on with this job and that I really had to look for something else. (R9) 
CDI 26,4

For others, the first career decision was to resign from their job to start a business later on:

I just quit my job and learn something I can start a business with. (R8)

Here it also became evident that in the long run negative career shocks did not necessarily have a negative impact on the individual's career. One respondent commenting on the impact of being rejected for a $\mathrm{PhD}$ position said:

But in the long run right now I am very happy that this happened because this led me to concentrate on only two options, and then I put founding the company first. (R7)

\section{Negative career shocks after starting a business}

Like the positive shocks after starting a business, negative career shocks after the founding of the business predominantly occurred in the professional domain.

Business-related challenges. Business challenges originated from both the business and personal strains originating from the business. Examples were setbacks that delayed the process or hindered the development of the business, and mistakes that were sometimes made due to inexperience (e.g. dealing with an investor, R17) or needing to change the name of the company as another company was already using it (R25). Moments of business setbacks were often linked with major disappointments. For example, working hard to get an investor who then ultimately rejected the deal (R4). Furthermore, certain negative shocks were connected to activities that were performed for the first time:

Thus, you know the very first time we pitched to an investor, it was a complete drama, like a doctor, he would take his little knife, his scalpel and cut our idea in slices and he messed us up completely. (R6)

Moreover, the newly graduated entrepreneurs described moments when they experienced personal strains in the process of starting up a business. Those moments referred to struggles with not having an income (R21) or feeling down and insecure (R9). Another respondent described how the moments in which he became aware of his responsibility and the growing pressure:

We are 23 people now, and it sounds successful and cool and stuff. [.. .] And it works out. But it can still be over in four months or five more or less because the more you grow [. . . the harder it is if one month doesn't work out like this. (R3).

Co-worker changes. A co-worker, often the co-founder, unexpectedly leaving the company can be a significant negative shock for a newly graduated entrepreneur:

Another moment was when my business partner left, that was also a really big turning point. (R16)

Other important moments for new entrepreneurs were when they had to dismiss the first employee or a co-founder. As newly founded companies are typically small, significant people leaving the business can be quite influential because the co-workers were often befriended:

At a certain point [it] meant that we had to get rid of one of the co-founders, which morally didn't really feel right, possibly we could have handled that a bit nicer. But it caused the whole business to just drag on and not really be progressive in any way. (R19)

\section{Impact of negative career shocks after starting a business}

Negative career shocks after founding the business influenced entrepreneurs personally and professionally. Interestingly, only one impact of negative career shocks is clearly a negative impact.

Doubts about entrepreneurship. In the process of founding the business, negative shocks related to business setbacks and co-worker changes lead to doubts about entrepreneurship. 
The respondents questioned their decision to pursue an entrepreneurial career by comparing the entrepreneurship with careers as an employee:

In these down parts, you sometimes think why I am not just an employee. (R3)

Especially the co-worker changes such as the departure of the co-founder led to doubts about continuing the business alone:

Because the day he told me [that he will leave] I was like wow should I just quit (R16).

Moreover, business-related challenges caused entrepreneurs to express uncertainty about their own business and their plan for the business. After being turned down by an investor, one respondent speculated whether it was sensible to instead focus on another business idea (R1). Other respondents questioned their product (R6) or the impact of the business (R9).

Entrepreneurial maturity. Respondents indicated that career shocks related to businessrelated challenges and co-worker changes influenced entrepreneurial maturity as statements pointed toward learning from those setbacks, overcoming weaknesses and gaining the leading position. Entrepreneurial maturity refers to having an understanding of what it means to be an entrepreneur, developing oneself as an entrepreneur and becoming more experienced in business-related tasks. The following quote illustrates this process:

In the beginning, we were more "the students" and now we are getting more "the entrepreneurs." (R17).

The findings suggested that starting a business was a learning process for newly graduated entrepreneurs and that the impact of such career shocks typically develops over time into a positive outcome. Entrepreneurial maturity also refers to gaining the leading position in the business and, thus, having full control over the business as well as the decisions that must be made. Therefore, the negative shock of the exit or dismissal of the co-founder had a potentially positive impact of gaining sole responsibility for the business:

I was very grateful about that, it was my intention also, not to get rid of everybody but I did want to take on the leading position, and I did [...] now I'm very happy with the way we're doing things because I can just manage it myself and I have the final call in everything. (R16)

\section{Discussion}

\section{Main findings and theoretical implications}

This study contributes to research on career shocks by revealing the interplay between events outside of the individual's control and the agentic decision-making processes. Newly graduated entrepreneurs experience different types of career shocks. For example, unexpected meetings with significant others, sudden major learning experiences in a university course and winning awards were all external events that had an important influence on them. However, the newly graduated entrepreneurs made their own deliberations based on these events, with some of them deciding to change things up, while others continued their existing career path. Thus, the results stress the importance of incorporating career shocks in the scholarly discussion on contemporary careers and studying career shocks over time (Akkermans et al., 2018). Additionally, this study's results support calls in the career literature that career research should include both agency and contextual factors (e.g. Akkermans and Kubasch, 2017; Inkson et al., 2012; Mayrhofer et al., 2007).

While a deliberate thinking process is inherent to a career shock, such a thinking process does not necessarily need to lead to a career change. We found that both positive and negative career shocks could lead individuals to change their career path and pursue entrepreneurship; however, such shocks can also lead to doubts, continuation and even the reinforcement of career paths, as illustrated by the reference our respondents made to increased entrepreneurial 
CDI

26,4

maturity. For example, someone who initially opted for a corporate career could suddenly be faced with a career plateau in their organization, which may ultimately lead them to quit their job and pursue an entrepreneurial career. However, in other cases, negative career shocks do not necessarily have to lead to a career change. Confronted with the negative shock of receiving harsh critique during a business plan competition, some graduates only experience doubts and do not decide to stop developing their business and others emphasize the learning process that occurs after such a negative shock. In all, it would be important to incorporate other elements of career shocks, such as their intensity or frequency (cf. Akkermans et al., 2018) to fully understand their potential impact. For example, a person might need to experience a highly significant event (e.g. being laid off, losing a loved one) or a number of "smaller" events (e.g. multiple peers leaving the business or organization over a span of time) before reaching a threshold that causes a change in career-related behavior.

Furthermore, whether and how often shocks are experienced may also be a function of the population under investigation. Entrepreneurs may experience more shocks due to their proactive personalities (Seibert et al., 2001), as well as entrepreneurship being a more uncertain and less structured career path (Schindehutte et al., 2006). Moreover, entrepreneurs may be better capable to deal with career shocks as they are more adaptable and thus are better at coping with negative career shocks (Chadwick and Raver, 2018). In this entrepreneurs differ from regular employees, underlining the importance of studying entrepreneurs as a separate group.

As a second contribution, our study is also relevant for school-to-work transition literature (e.g. Brzinsky-Fay, 2007; Ng and Feldman, 2007). Most school-to-work transition literature focuses on a traditional transition from education into employment in an organization; however, scholars have called for research into non-typical transitions after graduation (e.g. Schoon, 2015). Our findings illustrate that career shocks can play an important role during the school-to-work transition, and that they can lead graduates to pursue an entrepreneurial career after graduation. Furthermore, the results demonstrate the complexity of this transition and offer a better understanding of the factors influencing the entrepreneurial decision. In doing so, this study provides further substance for graduate-to-entrepreneur transition studies (Nabi et al., 2009, 2010) by showing that graduates experience both positive and negative career shocks during the transition to entrepreneurship. Moreover, this study's findings suggest that career shocks not only potentially serve as a trigger for a particular type of first employment, but that shocks can even alter the chosen career path after the school-to-work transition. Some of the respondents initially focused on a corporate career; however, positive and negative career shocks triggered them to start a business. Thus, career shocks can lead university graduates to pursue a different transition pathway than the traditional transition into paid employment.

Our study also contributes to entrepreneurship literature. While much of the entrepreneurial career choice literature emphasizes entrepreneurial intentions (cf. Krueger et al., 2000) - closely related to how career research has emphasized individual agency - our findings on career shocks are closely related to the triggers discussed by Shapero and Sokol (1982). In line with their thinking, both negative and positive career shocks trigger business creation. As such, our findings provide an impetus for entrepreneurship research to include career shocks in research on agency-related concepts such as entrepreneurial intention, as this opens the possibility to study when and why intentions develop and change. Our findings further reveal that career shocks can be linked to both opportunity (pull) and necessity (push) classifications (Bosma and Harding, 2006), and as such the construct of career shocks is significant for any of these types of entrepreneurship. Like previous findings (cf. Nabi et al., 2015) that the motivations for entrepreneurship can operate concurrently, so can a combination of shocks. For example, the positive shock of influential people and the negative shock of working in a corporate environment can conjointly influence recent graduates to start a business. Furthermore, in contrast to the two classifications which are 
focused on the decision to become an entrepreneur, our findings show that career shocks are not only relevant for the initial decision to start up but that newly graduated graduates also experience shocks after founding their business. Career shocks before starting a business were often personal, whereas shocks that occurred after the founding of the business were often professional, suggesting that the context in which shocks are experienced can influence the type of shocks and their impact on careers.

\section{Limitations and future research}

This study's results also showed that it is difficult to pinpoint exactly the boundaries of what a career shock is and what its impact may be. Although we followed the conceptualization of Akkermans et al. (2018) in our interview questions, career shocks are subjective experiences, and it is possible that some of the career shocks that were reported do not fully qualify as a career shock based on the definition used. For example, certain events may have been unexpected and significant for the entrepreneur but did not cause a deliberate thinking process. Similarly, being unhappy with an organizational career might be a shock if it comes as a sudden realization based on an external event; however, it could also be a gradual process based on (a lack of) intrinsic motivation. Thus, while the conceptualization of Akkermans et al. (2018) offers helpful dimensions to research career shocks, this study indicates that it can be difficult to delineate empirically what constitutes a career shock. Future research may do further work to operationalize characteristics of career shocks and their possible impacts.

A limitation of our study is that we only studied active entrepreneurs and, therefore, did not investigate the career shocks and the impact thereof on those entrepreneurs who transitioned out of entrepreneurship. In other words, we studied shocks into entrepreneurship but missed shocks out of entrepreneurship. A future study could sample graduated entrepreneurs and former entrepreneurs to investigate similarities and differences with our findings. One possibility is that such a study would find a more uniformly negative impact of negative career shocks among people who moved out of entrepreneurship compared to the emphasis on learning from negative shocks in our current sample. Relatedly, a future study could compare graduates who are shocked into entrepreneurship with those who are not, to establish which career shocks are more likely to be associated with employment or entrepreneurship. Yet another comparison would be between those who become an entrepreneur as a result of a career shock and those for whom no such shock played a role.

Furthermore, as we specifically asked for the impact of career shocks, shocks that may not have had any concrete impact on careers might be underrepresented in our findings. Whereas career shocks with a high intensity were likely reported, career shocks with a high frequency (but possibly lower intensity) may not have been mentioned. Moreover, the interplay between the roles of the external event vs agentic factors needs more examination. Therefore, an important challenge for future research concerns the identification of boundary conditions of the application of the career shock construct when it comes to entrepreneurial career choice: some may have become entrepreneurs regardless of the career shocks happening to them, while conversely, there may be certain individuals who will never opt to be an entrepreneur, whatever happens.

Our study focused specifically on the role of events that may have impacted newly graduated entrepreneurs. This has generated important new knowledge that complements the existing literature that emphasizes agency and entrepreneurial intentions. A next step could be to study when, where and for whom certain events may or may not lead to deliberate thinking and potentially career changes. Thus, future studies could examine how individual differences, whether in traits or capabilities, interact with major events in terms of generating deliberate thinking, and potentially causing career changes. Similar events may lead to a variation in terms of deliberate personal reflection and impact on career outcomes, and future 
CDI 26,4

research may want to model such interaction effects. Appraisal Theory (Lazarus and Folkman, 1984) may provide helpful guidance here as it comprises the assessment of threat, loss and opportunity in the primary appraisal, coping options in the secondary appraisal, and actual coping; thus, bringing together the elements involved in encountering and responding to career shocks.

\section{Practical implications}

First, this study's findings are relevant to organizations and policymakers. In the context of the ongoing "war for talent," it is essential for organizations to retain and attract qualified young employees ( $\mathrm{Ng}$ et al., 2010). Moreover, the entrepreneurial behavior of employees is an important success factor for organizations because it is linked to growth and adaptability to the quickly changing environment (Rigtering and Weitzel, 2013). As most newly graduated entrepreneurs experienced a negative shock related to working in an organization before pursuing starting their own business, this study's findings imply that these "to be" entrepreneurs missed certain important characteristics such as autonomy in their jobs. Therefore, incorporating aspects that are valued by entrepreneurial graduates can be essential for companies to attract and retain young talented workers. The reported deficiencies of working in an organization (e.g. lack of autonomy, presence of strong hierarchy) illustrate the aspects that are valued by graduates and might be integrated into the job design and organizations' career development programs, as well as into the employer branding activities.

Second, universities and governments seek to increase the entrepreneurial activities of graduates, whether in existing corporations or independent new ventures, as entrepreneurship is seen as a source for economic growth. This study's results show that positive career shocks such as meeting significant people, having role models, and getting entrepreneurial encouragement, triggered graduates to become entrepreneurs. By designing university programs and initiatives that foster these elements, an increasing number of graduates may consider starting a business or play entrepreneurial roles within existing organizations (Rigtering and Weitzel, 2013). Furthermore, the negative shocks during the process of starting a business, which lead individuals to doubt their entrepreneurial career decision and business, demonstrate that support should not stop at the point of the business creation but should be prolonged further into the process.

\section{References}

Akkermans, J. and Kubasch, S. (2017), "\#Trending topics in careers: a review and future research agenda", Career Development International, Vol. 22 No. 6, pp. 586-627.

Akkermans, J., Nykänen, M. and Vuori, J. (2015), "Practice makes perfect? Antecedents and consequences of an adaptive school-to-work transition", in Vuori, J., Blonk, R. and Price, R.H. (Eds), Sustainable Working Lives - Managing Work Transitions and Health throughout the Life Course, Springer, Dordrecht, pp. 65-86.

Akkermans, J., Seibert, S.E. and Mol, S.T. (2018), "Tales of the unexpected: integrating career shocks in the contemporary careers literature", South African Journal of Industrial Psychology, Vol. 44, pp. 1-10.

Amit, R. and Muller, E. (1995), “Push' and 'pull' entrepreneurship”, Journal of Small Business \& Entrepreneurship, Vol. 12 No. 4, pp. 64-80.

Arthur, M.B., Khapova, S.N. and Wilderom, C.P.M. (2005), "Career success in a boundaryless career world”, Journal of Organizational Behavior, Vol. 26 No. 2, pp. 177-202.

Baruch, Y. and Lavi-Steiner, O. (2015), "The career impact of management education from an averageranked university", Career Development International, Vol. 20 No. 3, pp. 218-237. 
Baruch, Y., Wordsworth, R., Mills, C. and Wright, S. (2016), "Career and work attitudes of blue-collar workers, and the impact of a natural disaster chance event on the relationships between intention to quit and actual quit behavior", European Journal of Work and Organizational Psychology, Vol. 25 No. 3, pp. 459-473.

Blokker, R., Akkermans, J., Tims, M., Jansen, P. and Khapova, S. (2019), "Building a sustainable start: the role of career competencies, career success, and career shocks in young professionals' employability", Journal of Vocational Behavior, Vol. 112, pp. 172-184.

Bosma, N. and Harding, R. (2006), "Global entrepreneurship monitor. GEM 2006 summary results".

Bright, J.E.H., Pryor, R.G.L. and Harpham, L. (2005), "The role of chance events in career decision making", Journal of Vocational Behavior, Vol. 66 No. 3, pp. 561-576.

Browne, K. (2005), "Snowball sampling: using social networks to research non-heterosexual women", International Journal of Social Research Methodology, Vol. 8 No. 1, pp. 47-60.

Bruyat, C. and Julien, P.-A. (2001), "Defining the field of research in entrepreneurship", Journal of Business Venturing, Vol. 16 No. 2, pp. 165-180.

Brzinsky-Fay, C. (2007), "Lost in transition? Labour market entry sequences of school leavers in Europe", European Sociological Review, Vol. 23 No. 4, pp. 409-422.

Burton, J.P., Holtom, B.C., Sablynski, C.J., Mitchell, T.R. and Lee, T.W. (2010), "The buffering effects of job embeddedness on negative shocks", Journal of Vocational Behavior, Vol. 76 No. 1, pp. 42-51.

Burton, M.D., Sørensen, J.B. and Dobrev, S.D. (2016), “A careers perspective on entrepreneurship”, Entrepreneurship Theory and Practice, Vol. 40 No. 2, pp. 237-247.

Chadwick, I.C. and Raver, J.L. (2018), "Psychological resilience and its downstream effects for business survival in nascent entrepreneurship", Entrepreneurship Theory and Practice, September 27, pp. 1-23.

Chen, C.P. (2005), "Understanding career chance", International Journal for Educational and Vocational Guidance, Vol. 5 No. 3, pp. 251-270.

Corbin, J. and Strauss, A. (1990), "Grounded theory research: procedures, canons, and evaluative criteria”, Qualitative Sociology, Vol. 13 No. 1, pp. 3-21.

Dawson, C. and Henley, A. (2012), "Push' versus 'pull' entrepreneurship: an ambiguous distinction?”, International Journal of Entrepreneurial Behavior \& Research, Vol. 18 No. 6, pp. 697-719.

GEM (2018), “GEM 2017/2018 global report”, Global Entrepreneurship Monitor, London Business School, London.

Gioia, D.A., Corley, K.G. and Hamilton, A.L. (2012), "Seeking qualitative rigor in inductive research", Organizational Research Methods, Vol. 16 No. 1, pp. 15-31.

Hall, D.T. (2004), “The protean career. A quarter-century journey”, Journal of Vocational Behavior, Vol. 65 No. 1, pp. 1-13.

Hirschi, A. (2010), "The role of chance events in the school-to-work transition. The influence of demographic, personality and career development variables", Journal of Vocational Behavior, Vol. 77 No. 1, pp. 39-49.

Holtom, B.C., Mitchell, T.R., Lee, T.W. and Inderrieden, E.J. (2005), "Shocks as causes of turnover: what they are and how organization can manage them", Human Resource Management, Vol. 44 No. 3, pp. 337-352.

Hulsink, W. and Koek, D. (2014), "The young, the fast and the furious: a study about the triggers and impediments of youth entrepreneurship", International Journal of Entrepreneurship and Innovation Management, Vol. 18 Nos 2/3, pp. 182-209.

Inkson, K., Gunz, H., Ganesh, S. and Roper, J. (2012), "Boundaryless careers: bringing back boundaries", Organization Studies, Vol. 33 No. 3, pp. 323-340.

Kalleberg, A.L. and Marsden, P.V. (2015), "Transformation of the employment relationship", in Scott, R.A. and Kosslyn, S.M. (Eds), Emerging Trends in the Social and Behavioral Sciences, John Wiley \& Sons, Hoboken, NJ, pp. 1-15. 
CDI 26,4

Kautonen, T. and Palmroos, J. (2010), "The impact of a necessity-based start-up on subsequent entrepreneurial satisfaction", International Entrepreneurship and Management Journal, Vol. 6 No. 3, pp. 285-300.

Kollmann, T., Stöckmann, C., Henselleck, S. and Kenbock, J. (2016), "European startup monitor".

Krueger, N.F., Reilly, M.D. and Carsrud, A.L. (2000), "Competing models of entrepreneurial intentions", Journal of Business Venturing, Vol. 15 Nos 5-6, pp. 411-432.

Lazarus, R.S. and Folkman, S. (1984), Stress, Appraisal, and Coping, Springer, New York, NY.

Lee, T.W. and Mitchell, T.R. (1994), "An alternative approach. The unfolding model of voluntary employee turnover", Academy of Management Review, Vol. 19 No. 1, pp. 51-89.

Lerner, D.A., Hunt, R.A. and Dimov, D. (2018), “Action! Moving beyond the intendedly-rational logics of entrepreneurship”, Journal of Business Venturing, Vol. 33 No. 1, pp. 52-69.

Locke, K. (2001), Grounded Theory in Management Research, SAGE Publications, Thousand Oaks, CA.

McLarty, R. (2005), "Entrepreneurship among graduates. Towards a measured response", Journal of Management Development, Vol. 24 No. 3, pp. 223-238.

Mayrhofer, W., Meyer, M. and Steyrer, J. (2007), "Contextual issues in the study of careers", in Gunz, H.P. and Peiperl, M. (Eds), Handbook of Career Studies, SAGE Publications, Thousand Oaks, CA, pp. 215-240.

Morrell, K., Loan-Clarke, J. and Wilkinson, A. (2004), "The role of shocks in employee turnover", British Journal of Management, Vol. 15 No. 4, pp. 335-349.

Nabi, G. and Holden, R. (2008), "Graduate entrepreneurship: intentions, education and training", Education + Training, Vol. 50 No. 7, pp. 545-551.

Nabi, G., Holden, R. and Walmsley, A. (2006), "Graduate career-making and business start-up: a literature review”, Education + Training, Vol. 48 No. 5, pp. 373-385.

Nabi, G., Holden, R. and Walmsley, A. (2009), "Graduating into start-up: exploring the transition", Industry \& Higher Education, Vol. 23 No. 3, pp. 199-207.

Nabi, G., Holden, R. and Walmsley, A. (2010), "From student to entrepreneur: towards a model of graduate entrepreneurial career-making", Journal of Education and Work, Vol. 23 No. 5, pp. 389-415.

Nabi, G., Walmsley, A. and Holden, R. (2015), "Pushed or pulled? Exploring the factors underpinning graduate start-ups and non-start-ups", Journal of Education and Work, Vol. 28 No. 5, pp. 481-506.

Ng, E.S.W., Schweitzer, L. and Lyons, S.T. (2010), "New generation, great expectations: a field study of the millennial generation”, Journal of Business and Psychology, Vol. 25 No. 2, pp. 281-292.

Ng, T.W.H. and Feldman, D.C. (2007), "The school-to-work transition: a role identity perspective", Journal of Vocational Behavior, Vol. 71 No. 1, pp. 114-134.

Rigtering, J.P.C. and Weitzel, U. (2013), "Work context and employee behaviour as antecedents for intrapreneurship", International Entrepreneurship and Management Journal, Vol. 9 No. 3, pp. 337-360.

Schindehutte, M., Morris, M. and Allen, J. (2006), "Beyond achievement: entrepreneurship as extreme experience", Small Business Economics, Vol. 27 Nos 4-5, pp. 349-368.

Schoon, I. (2015), "Diverse pathways: rethinking the transition to adulthood", in Amato, P.R., Booth, A., McHale, S.M. and Van Hook, J. (Eds), Families in an Era of Increasing Inequality: Diverging Destinies, Springer International Publishing, Cham, pp. 115-136.

Seibert, S.E., Kraimer, M.L. and Crant, J.M. (2001), "What do proactive people do? A longitudinal model linking proactive personality and career success”, Personnel Psychology, Vol. 54 No. 4, pp. 845-874.

Seibert, S.E., Kraimer, M.L., Holtom, B.C. and Pierotti, A.J. (2013), "Even the best laid plans sometimes go askew: career self-management processes, career shocks, and the decision to pursue graduate education”, The Journal of Applied Psychology, Vol. 98 No. 1, pp. 169-182. 
Shapero, A. (1984), "The entrepreneurial event”, in Kent, C.A. (Ed.), The Environment for Entrepreneurship, Lexington Books, Lexington, MA, pp. 21-40.

Shapero, A. and Sokol, L. (1982), "The social dimension of entrepreneurship", in Kent, C.A., Sexton, D. and Vesper, K.H. (Eds), The Encyclopedia of Entrepreneurship, Prentice Hall, Englewood Cliffs, NJ, pp. 72-90.

Slay, H.S., Taylor, M.S. and Williamson, I.O. (2006), "Midlife transition decision processes and career success: the role of identity, networks, and shocks", In annual meeting of the Academy of Human Resource Development, Austin, TX.

Van Gelderen, M., Brand, M., Van Praag, M., Bodewes, W., Poutsma, E. and Van Gils, A. (2008), "Explaining entrepreneurial intentions by means of the theory of planned behaviour", Career Development International, Vol. 13 No. 6, pp. 538-559.

Voutsina, K., Mourmant, G. and Niederman, F. (2014), "The range of shocks promoting entrepreneurial employee turnover through the lenses of exploration and exploitation framework", in Stettner, U., Aharonson, B.S. and Amburgey, T.L. (Eds), Exploration and Exploitation in Early Stage Ventures and SMEs (Technology, Innovation, Entrepreneurship and Competitive Strategy Volume 14), Emerald Group Publishing Limited, August 4, pp. 39-66.

\begin{abstract}
About the authors
Sophie Rummel is an HR expert and researcher connected to the Vrije Universiteit Amsterdam, the Netherlands. Building on a Bachelor' Degree in Business Psychology from the SRH Hochschule Berlin, she continued with a Master' Degree in Human Resource Management at the Vrije Universiteit Amsterdam. During her Master studies she was Student Assistant for the Project Management Journal. Thus far her research focuses on career shocks influencing career development.

Jos Akkermans is Associate Professor of Sustainable Careers and Organizational Behavior at Vrije Universiteit Amsterdam, the Netherlands. His research mostly focuses on sustainable career development, employability and major career transitions. He has published his work in leading journals such as Journal of Vocational Behavior, Human Resource Management Journal, and European Journal of Work and Organizational Psychology. Jos is Associate Editor for Journal of Vocational Behavior and currently part of the executive team of the Academy of Management Careers Division. Jos Akkermans is the corresponding author and can be contacted at: j.akkermans@vu.nl

Rowena Blokker is working as PhD Candidate at the Department of Management and Organization at Vrije Universiteit Amsterdam, the Netherlands. Her research focuses on the school-to-work transition and young people's career development. Specifically, she aims to contribute to the development of theory and curriculum on the transition from university to work in today's dynamic labor market. Further, Rowena is a board member of $\mathrm{PhD}$ Research community (pHResh).

Marco Van Gelderen is a Business Psychologist specializing in Entrepreneurship. Marco focuses his research as well as his teaching activities on individual level enterprising competencies. For research overviews of these competencies, see a website that Marco maintains: www.enterprisingcompetencies. com. Marco is currently editor of the learning innovation section of the Entrepreneurship Education \& Pedagogy Journal. Furthermore he is an editorial board member of the Journal of Business Venturing and of Entrepreneurship Theory \& Practice.
\end{abstract}

For instructions on how to order reprints of this article, please visit our website:

www.emeraldgrouppublishing.com/licensing/reprints.htm

Or contact us for further details: permissions@emeraldinsight.com 